\title{
(Im)politeness and alignment
}

\section{A case study of public political monologues}

\author{
Dániel Z. Kádár \\ Dalian University of Foreign Languages; \\ Research Institute for Linguistics, \\ Hungarian Academy of Sciences \\ dannier@dlufl.edu.cn

\section{Sen Zhang} \\ Dalian University of Foreign Languages \\ zhangsen@dlufl.edu.cn
}

\begin{abstract}
This paper aims to examine the role of (im)politeness and alignment in public monologues. Linguistic politeness theory has predominantly focused on the interpersonal aspect of (im)politeness, and we know relatively little about forms of (im)politeness that do not serve a direct interpersonal function but rather aim to form a sense of alignment with an indefinite group of recipients. We define such form of pragmatic behaviour as 'alignment', to distinguish it from politeness as an interpersonal form of interaction. Forms of alignment may operate in a duality with interpersonal (im)politeness, and they represent the default mode of relational involvement in public discourses - in particular, in public monologues. We argue that forms of alignment cannot be ignored in politeness research due to their prevalence in certain genres/modes of communication, and also because their operation can be intriguingly complex from a politeness theoretical point of view, considering their dual relationship with (im)politeness. We use data drawn from Chinese political discourse as a case study to illustrate this dual relationship.
\end{abstract}

Keywords: (im)politeness; alignment; monologue; public discourse; Chinese political language use

\section{Introduction}

The present paper aims to contribute to linguistic politeness research, by examining (im)politeness and alignment as dual phenomena in the context of formal monologues in public discourses drawn from the political arena. Our interpretation of 'monologue' includes both spoken and written modes of communication (Schafer 1981). Alignment in our understanding covers the discursive attitude of reinforcing feelings of solidarity - in particular but not exclusively, the feeling of belonging together - with others. Intersubjective alignment is somewhat similar to what psychologists such as Spencer-Oatey's (2000) interpret as 'rapport' in groups. However, unlike rapport, we do not use alignment to refer to interpersonal interaction 
in the respect that, in terms of participation (Goffman 1981) alignment includes forms of communal behaviour that are not directed towards a particular recipient/group of recipients but rather are meant to be overheard by the ratified 'public' (Roche et al. 2010). More specifically, while alignment may occur in interpersonal interaction, it is not limited to such interactions but also includes communicative behaviour in public discourse. Accordingly, while alignment just as rapport is likely to create a feeling of solidarity (Spencer-Oatey \& Žegerac 2017), such feeling of solidarity is not necessarily personal in the respect that the addressees of an utterance or a discourse that triggers alignment may never know each other. ${ }^{1}$ Intersubjective alignment is strongly interconnected with implicitness (Harris et al. 2006), even though it can manifest itself in explicit forms as well: as far as in public discourses there is no direct addressee involved, alignment usually operates in an implicit way. We believe that alignment provides a key contribution to the inventory of linguistic politeness research: to date little research has been dedicated to this phenomenon, even though a very limited number of studies (mainly outside of the scope of linguistic politeness research) such as de Jong et al. (2008) and Tanaka et al. (2002) have inquired into this area. We define alignment as a phenomenon that concurs with (im)politeness as a duality. While we explain the nature of this duality below, essentially it refers to the fact that alignment in certain genres/discourse types such as the ones studied is the default mode of relational engagement rather than (im)politeness, but (im)politeness may become relevant and, in a sense, 'collaborate' with alignment. To investigate the alignment-(im)politeness duality, we focus on (written) monologues; by 'monologue' we refer to longer speeches which are generically and contextually not supposed to trigger dialogic response. We examine formal monologues in public discourses, such as news talks, announcements made in public, and ceremonial speeches.

Note that our focus in the present paper is limited, in that we only focus on the pragmatic features of alignment. Clearly, the study of this phenomenon calls for a broader investigation involving for instance the psychology of alignment and the influence of psychological factors on language production. While it is beyond the scope of our research to investigate such issues, we hope that our research will trigger further academic discussions.

${ }^{1}$ Note that while rapport is understood as a form of behaviour in which politeness is a key part, we interpret alignment differently from politeness in a dual sense. 


\section{Literature review}

Linguistic politeness research has pursued interest predominantly in interpersonal interaction (see an overview in Eelen 2001). While monologic genres such as poems have received some limited attention in historical (im)politeness research (Kádár \& Culpeper 2010; He \& Ren 2016), they have remained relatively marginal because their study does not fully fit into the 'mainstream' analytic agenda of the field. Since the post-2000 politeness paradigm largely agrees that (im)politeness comes into existence vis-à-vis evaluative moments (e.g., Watts 2003), monologues have relatively little to offer to understandings of how politeness and impoliteness come into existence. Areas such as stylistics and discourse analysis (e.g., Huckin 2002) have used the politeness paradigm to study monologues, but such research - having been mostly anchored in the pre-discursive Brown and Levinsonian (1987) paradigm (see Kádár 2019, in the present issue) - has delivered a limited contribution to advances in politeness studies. In addition, formal monologues in public discourses have received little attention, compared to, for instance, literary monologues (Leech 2008). Importantly, this relative lack of interest in the pragmatic genre of monologues does not mean that the inventory of politeness research could not cope with the analysis of monologic data, including monologues written to the public rather than an individual addressee. Written discourse analysis has been broadly used in the politeness field (e.g., Locher \& Watts 2005; GarcésConejos Blitvich 2010; Chen 2017), and when it comes to monologues there are various ways such as the concept of 'discursive move' (Locher 2006) through which one can capture attempts to be polite in written genres such as public monologues. The issue is rather that monologues (in particular those delivered to public audiences in writing) can only be understood as being 'interactional' in a broader context, i.e., one can examine the evaluation of a monologue only outside of the immediate space and time in which takes place.

Yet, monologues in public discourse are definitely not without interest for the politeness researcher. On the one hand they represent an important relational channel of language use with complex participation framework beyond that of dialogic ${ }^{2}$ interactions (Kádár 2017). On the other hand, their study raises questions that may not be self-evident in the context of studying dialogic data, such as how one can analyse the interconnection between rhetoric and intersubjectivity (Kádár \& Zhang 2019). In the present

2 Note that by 'dialogue' we do not necessarily mean two-party interaction, but rather interactions in which there are several interactants. 
paper, we explore the question as to how it is possible to capture the intersubjective nature of monologues in terms of politeness theory, through the understanding of politeness and alignment as dual phenomena (see also Liu \& Shi 2019, in the present issue). Ours is a 'position paper', in the respect that we report on the outcome of an ongoing major project dedicated to the politeness theoretical study of alignment in political discourses (see Kádár \& Zhang 2019; see also section 2).

We argue that while it is possible to analyse certain words, discursive moves, and other forms of pragmatic behaviour in monologues as 'polite' or 'impolite' by assuming that they express a positive meaning towards the recipient, ultimately '(im)politeness' per se as a term may be of limited use to cover what is going on in many types of formal and public monologues, such as political announcements studied in this paper. That is, provided that one interprets politeness in a technical sense (Kádár \& Haugh 2013) as a form of interpersonal behaviour, one may need to rethink its use since certain forms of public discourse such as these types of monologues are hard-wired to create a sense of alignment (e.g., the feeling of belonging together) with large number of recipients. This does not mean, in our view, that (im)politeness as a phenomenon may not be relevant to the analysis of such texts, but rather that we need to critically consider its role. Thus, alignment offers an alternative analytic concept to examine monologues, hence delivering a key conceptual contribution to offer to politeness theory: we argue that in order to understand the dynamics of public monologues, one needs to rigorously distinguish the concepts of 'alignment' and '(im)politeness'.

The phenomenon of alignment is supposedly relevant to the study of any form of monologic public discourse, as well as other types of interactions (in particular, public ones) involving a complex participatory framework. In the present paper we demonstrate this point by using political monologues as a case study. Political monologues are worth studying because - unless a politician addresses the public in a free-flowing fashion (see e.g., Tracy 2017, 742) - (s)he needs to strengthen the public's sense of interconnectedness without being de facto polite. That is, while political monologues may include terms of address and other forms by means of which the speaker may personalise the monologue, in the realm of public discourse, monologue is essentially a spoken or written text (Bull \& Fetzer 2010) that may appeal to the recipient but may not deliver politeness in a personalised fashion. For example, by talking about 'American values' a North American politician may form alignment with her or his electors without being polite in the technical sense of the word. In hierarchical 
political cultures such as Chinese (Yang 1997), alignment is a phenomenon particularly worth investigation: due to the prevailing power difference between Chinese political stakeholders and the public, it may be alien to the Chinese political discursive style to display politeness towards the public beyond a certain degree, or even to directly address the public in many contexts. This also implies that, if (im)politeness occurs in such communicative settings, it has a specific indexical (Agha 2007) function.

\section{Analytic model}

While previous research has examined the pragmatics of intersubjective alignment in discourses to a certain degree (Bucholtz 2009; Kádár \& Zhang 2019), there has been little research on how alignment relates to politeness and impoliteness. Alignment itself is a complex phenomenon that would deserve more attention in pragmatics: it represents a communal aspect of language use, and it operates through a cluster of moral and affective stances (Goodwin 2007) that the animator (Goffman 1981) of a monologue in public discourse takes. In the present paper, we do not devote so much focus on how to 'systemise' alignment. Rather we focus on instances when politeness and impoliteness become relevant in monologues, in order to illustrate how such instances of relevance can be captured in relation to alignment. Note that salience has been studied in different communicative contexts: perhaps most importantly, Watts's (2003) relational framework distinguishes 'politic' and 'polite' behaviours, in the context of interpersonal politeness. In Watts's (2003) interpretation, 'politic behaviour' refers to the interpersonal behaviour that is normally expected in a particular context, whilst 'politeness' indicates instances of language use when the speaker goes beyond such contextually required form of behaviour, by investing some extra effort to be polite towards the others. The alignment-politeness duality studied in this paper is different from the politic-polite dichotomy. In the centre of our model is the above discussed indexicality of (im)politeness in pragmatic genres (Garcés-Conejos Blitvich 2010), such as monologues, in which alignment is the 'default' and ongoing mode of relational work. The indexicality of (im)politeness implies that in such genres (im)politeness may be directed at an alternative recipient with attributed agency rather than the ordinary recipients (i.e., the public). Also, such forms of indexical (im)politeness are contextually embedded and they may ultimately reinforce the aligning relational function of monologues (see Liu \& Shi 2019, in the present issue). 
Attributed agency (Cooren 2008) and related accountability play a key role in the operation of alignment and (im)politeness in public monologues. That is, as far as (im)politeness is not addressed to the public in a monologue, it is usually directed towards actors with agency, in the respect that a monologue may express politeness and impoliteness towards groups and individuals if they can be held accountable for something referred to in the monologue (Johnson 2017). For instance, a political speaker may express politeness towards an organisation who helped their party to achieve a goal, or impoliteness towards a political organisation that is morally constructed as the 'enemy'. Ultimately, such (im)polite instances may or may not be important to the recipients themselves - for instance, in the case of political exchange of aggressive messages between countries there is perhaps no personal 'face-threat' involved by default. It is rather that such (im)polite instances are meant to reinforce alignment between the animator of the monologue and the recipients, i.e., they may operate as implicit parts of the alignment work.

Figure 1 illustrates this relationship between (im)politeness and alignment:

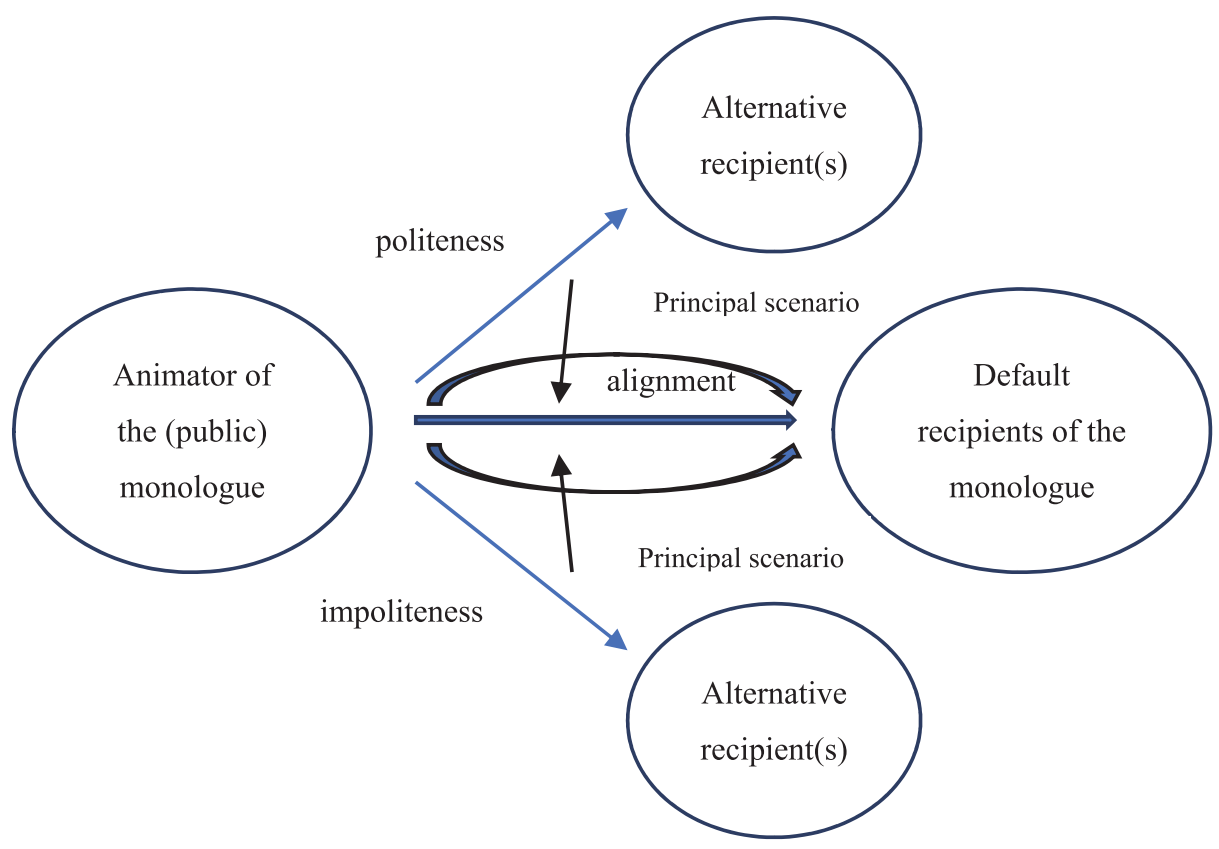

Figure 1: Alignment and politeness in monologues 
In the figure, the straight bold arrow indicates that alignment is the 'default' mode of relational work in public monologues, whereas politeness and impoliteness may represent alternative pragmatic engagement. The arrows pointing from politeness and impoliteness to alignment illustrate that (im)politeness engagement in public monologues may also be part of their aligning function. The curved arrows indicate a specific situation which we outline in the following paragraph.

The pragmatic 'division of labour' between alignment and politeness may only be valid in instances of public monologues in which the person who delivers a monologue is only its animator, i.e., the monologue type studied in this paper. The discursive dynamics may change once - in the terms of Goffman (1981) - the person who delivers the monologue is its ratified principal, i.e., when the line of the talk changes and the monologue is delivered by the writer/speaker as an individual. For instance, if a monologue is not made on the behalf of a group or organisation, or if the person who delivers it is ratified to directly communicate with the recipients - i.e., when a monologue ceases to be strictly formal - the speaker may attempt to be directly polite towards the default recipients. Or, if a formal monologue is somehow disrupted, say, a heckling event occurs, the monologue may transform into a dialogue (Kádár 2017), and the participants of the dialogue may engage in a directly (usually impolite or at least aggressive) exchange. The curving arrows in Figure 1 illustrate such cases as 'principal scenarios', i.e., scenarios in which the participatory role of the person who delivers the monologue transforms from an animator to that of principal. Due to space limitations, in the present paper we only focus on cases in which a formal monologue is delivered by an animator who is not assuming the role of principal.

\section{Data}

The present research aims to capture the operation of alignment and politeness in monologues, by analysing data drawn from the genre of monologic Chinese political discourse of gong'gao 公告 ('public announcement'). The genre of gong'gao is different from press conferences - which have been more broadly studied both in English (e.g., Bhatia 2006) and Chinese (e.g., Jiang 2006; see also Liu \& Shi 2019) - in that public announcements are written/scripted monologues, and so they do not trigger immediate response (e.g., questions after a press conference). One may argue that gong'gao is the archetype of public dialogue, while at the same time its sociopragmatic operation accords with that of any political genre, in that 
it is 'designed for overhearing listeners even more than the actual party addressed' (Tracy 2017, 742). Thus, gong'gao is an example par excellence to study language use in formal and public monologues, and due to its written nature, it does not allow the above-discussed 'principal scenario' (see Figure 1) to occur.

We comparatively examined two gong'gao datasets that represent significantly different types of interactional engagement. On the one hand we investigated news releases of gong'gao during the Vaccine Scandal that broke out in China in the summer of 2018 (see also Kádár \& Zhang 2019). This incident started when the national media released information on a 'potential' problem with 'a limited number of vaccines'. It quickly became evident that the situation was significantly worse than this euphemistic wording suggested: a huge number of patients had been improperly vaccinated against life-threatening illnesses such as rabies. This first Vaccine Scandal dataset consists of 40 monologues, including 30 national-level announcements, five provincial-level announcements and five local-level announcements that were made in the media following the outbreak of the incident. As our analysis in section 4 will illustrate, in China the level of the authority in the decision-making hierarchy has direct relationship with the interrelation of alignment and (im)politeness in the texts studied, in particular if the key message of the monologue is to reassure the public that stakeholders on the various levels effectively collaborate to resolve a national issue.

Along with this dataset, we examined 35 announcements made by the Ministry of Commerce between 23 January and 18 September, in the context of the recent Trade War that broke out between the U.S. and China. In this dataset the monologues are delivered only on the national level which accords with the fact that in China the national-level decision makers have the exclusive duty to respond to such conflicts. There is a small-scale discrepancy between the sizes of our datasets, in the respect that the Vaccine Scandal corpus consists of 5 more cases than the Trade War one. In our view this discrepancy does not significantly decrease the reliability of the analysis. From a sociopragmatic point of view, all gong'gao texts are contextually bound together in the respect that these announcements are infrequently released by the Chinese government or lower-level stakeholders, only in the wake of major social or economic crises. Furthermore, our datasets are similar in the respect that they consist of practically all the available online cases to date. ${ }^{3}$ Note that an advantage of studying

${ }^{3}$ We completed the present manuscript on the $10 / 11 / 2018$. 
gong'gao news releases is that they nearly always feature incidents of social importance: in Chinese politics the fact that a gong'gao is issued indicates that a matter of high importance has occurred. Previous research (e.g., Flowerdrew 1999) has demonstrated that events of crises trigger more intensive pragmatic engagement than 'ordinary' political settings, and so gong'gao news is certainly a valuable monologic dataset for the politeness scholar - we overview this difference in the following section.

\section{Analysis}

The comparison of the Vaccine Scandal and the Trade War datasets allowed us to examine different types of interactional involvement. The Vaccine Scandal dataset provides insight into cases in which alignment concurs with politeness. As our dataset has revealed, on the one hand these texts display aligning engagement with the public in the wake of a national crisis. On the other hand, they express deferential politeness to the authorities by positioning them as responsible leaders of the country, and by using honorifics and other lexical items. This discursive engagement in our view may be part of the engagement of aligning with the public: it is logical to argue that, by expressing politeness towards alternative recipients rather than the public in a public forum, these announcements aim to reinforce the public's trust in the politicians rather than simply being 'polite' in the conventional interpersonal sense of the word. The Trade War dataset represents the case where alignment concurs with a certain sense of 'impoliteness'. In these gong'gao announcements, the Chinese spokespersons deliver fundamentally impolite messages towards the U.S. government, by engaging in a morally-loaded discourse. Similarly to politeness in the Vaccine Scandal, impoliteness is not necessarily impolite here in the interpersonal sense, i.e., one can only speculate about whether it is meant to cause (and whether it did cause) any personal offence to American political stakeholders. Indeed, the ultimate intent may be to contribute to domestic alignment - by positioning the U.S. as an immoral party in the Trade War conflict, China is simultaneously positioned as the moral side.

Due to space limitations, in the present section we only feature two gong'gao excerpts as case studies (sections 3.1 and 3.2), and a brief section from another text in our discussion on why politeness may become a considerably complex phenomenon for study in public monologues (section 
3.3). Note that in both the Chinese text and the English translation we underline sections that we regard as particularly relevant to our analysis. ${ }^{4}$

\subsection{Alignment and politeness in the Vaccine Scandal dataset}

With the outbreak of the Vaccine Scandal, Chinese decision-makers delivered public announcements, in which they proposed a seven-point action plan; the most detailed description of this action plan is featured in (1).

（1）新华社北京7月25日电 为贯彻落实习近平总书记、李克强总理关于长春长生生物科技 有限责任公司违法违规生产狂犬病疫苗案件的重要指示批示精神，7月23日国务院调 查组赶赴吉林, 开展长春长生违法违规生产狂犬病疫苗案件调查工作。

7月24日, 国务院调查组组长、市场监管总局党组书记、副局长毕井泉主持召开调查 组第一次全体会议, 传达学习习近平总书记、李克强总理等中央领导同志 重要指示 批示精神, 要求调查组深入学习领会习近平总书记重要指示精神, 坚决贯彻落实李 克强总理重要批示要求, [...]

会议要求, 要重点围绕七个方面开展工作。一是彻查涉案企业违法违规行为, 全面 查清违法违规事实和涉案疫苗流向, 做好调查取证工作; 二是依法严惩违法犯罪行 为, 严肃查处涉案企业, 对直接责任人等涉案人员要依法严惩; 三是对公职人员履 职尽责进行调查, 发现失职渎职行为的要严肃问责; 四是科学开展风险评估, 研究 提出分类处理救济措施; 五是要妥善处理涉案企业后续工作; 六是要回应社会关切, 及时公布案件调查进展情况, 普及疫苗安全科学知识; 七是要研究改革完善疫苗管 理体制的工作举措, 建立健全保障疫苗质量安全的长效机制。根据工作需要, 调查 组下设案件调查组、监管责任组、综合组和专家组等工作组。

'Xinhua News reports on the 25th of July: The State Council Investigation Unit [ $\mathrm{im}$ mediately] implements the instructions of General Secretary Xi Jinping and Premier Li Keqiang about the illegal activities of Changchun Changsheng Biotech Ltd. Based on the higher instructions of the General Secretary and the Premier, on the $2 \overline{3 r d}$ of July the Investigation Unit proceeded to Jilin Province to investigate the matter of substandard rabies vaccines produced by the named company.

On the 24th of July, Bi Jingquan - the Principal Investigator of the State Council Investigation Unit and Party Secretary and Deputy Director of the State Administration for the Market Regulation Bureau - held the first comprehensive meeting to study the instructions of General Secretary Xi Jinping, Premier Li Keqiang and other important Cadres. Based on their higher instructions, the Principal Investigator demanded the Investigation Unit to intensively learn from General Secretary Xi Jinping and to determinedly implement the instructions and requirements in the key comments of Premier Li Keqiang. [...]

As an outcome of the conference, the delegates confirmed that they will deliver work on the following seven areas: First, they will thoroughly investigate the illegal actions of the corporation involved and will comprehensively investigate criminal activities in the corporation and the market flow of vaccines produced by the

${ }^{4}$ Due to space limitations we do not analyse all of the underlined parts individually, i.e., some of these sections are simply highlighted as references to our analysis. 
named company. Second, measures will be initiated to severely punish any behaviour that turns out to be illegal, in compliance with law. They will seriously examine the corporation involved in the incident and impose severe sanctions on persons directly responsible for the incident. Third, they will investigate public officials' fulfilment of their duties. Acts of dereliction should be seriously investigated. Fourth, they will conduct a risk assessment, propose classified measures for disposal and remedies based on research. Five, they will address the social crisis caused by the incident. Six, they will respond to public concerns with timely disclosure of information on the investigation and disseminate scientific knowledge about vaccine safety. Seven, they will carry out research on operational measures to improve and reform the current vaccine management system and establish and strengthen/develop long-term mechanisms for the maintenance of vaccine quality (and) safety. The Investigation Unit constitutes subordinate working units including a case-investigation unit, a regulatory responsibility unit, an integrated unit and an expert unit.' (www.gov.cn/xinwen/201807/25/content_5309213.html; cited from Kádár \& Zhang 2019)

The first part of the text represents politeness rhetoric. Xinhua News as a voice of the authorities endorses the individual actions of the leaders, by emphasising their agency (section 1.1) in resolving the crisis. One can only speculate about the interpersonal function of politeness - if there is any function at all - towards the national level decision makers. However, we may approach politeness here beyond its conventional interpretation, in accordance with the model proposed in Figure 1, as a form of discursive engagement that reinforces the aligning function of the monologue in the wake of a crisis. This function becomes evident if one examines the use of politeness in terms of agency: the monologue does not simply express deference to the leaders Xi Jinping and Li Keqiang but uses this form of expression to construct them as the only actors with agency in the crisis. This sense of agency is a key in the Chinese political cultural context, if one considers that in social crises of this kind, in hierarchical societies like the Chinese there tends to be a basic psychological need of coherent leadership action (Schermerhorn \& Bond 1997). While along with Xi and Li, the text also involves the Principal Investigator in charge of investigating the event, his action is framed as subordinate, as the text states that he 'demanded the Investigation Unit' to implement the higher order actions of the leaders. This, in turn, further reinforces the agency attributed to the leaders.

If one examines the politeness inventory of the narrative (see also Kádár \& Zhang 2019), it becomes evident that the spokesperson who delivers the gong'gao carefully chooses linguistic forms as per the discursive agenda, constructing the leaders as figures of responsibility in the crisis event. That is, the honorific expressions in the monologue are not simply deferential but also contribute to the discursive construction of the 
national leaders as decision makers in charge of the crisis. For instance, the monologue uses:

1. Guanche-luoshi 贯彻落实 'to implement higher orders', in reference to the course of action to be taken by Chinese investigators;

2. Zhongyao-zhishi pishi-jingshen 重要指示批示精神 lit. 'very important comments and instructions', in a similar fashion with guanche-luoshi;

3. Chuanda-guanche 传达贯彻 'to transfer the words of a higher-ranking person to others for study' and implement (their important instructions and comments) to describe the investigators' action in the context of the agentive authority of the leaders.

The sheer number of these expressions, and the repetitive way in which texts like (1) use them, indicate that they are parts of a ritualistic politeness activity: in the relatively brief excerpt above there are altogether eight such expressions. Their essential pragmatic function resides, in our view, in their agentive meaning.

Along with the use of honorifics, the text illustrates another form of politeness behaviour that characterises our data: it expresses politeness towards the national leaders in an implicit way, by indicating the promptness of their reactions. Notably, the authors of such gong'gao texts do not use words such as 'quick' in this context to refer to the actions of Xi Jinping and Li Keqiang, i.e., it remains the reader's task to draw the implication. However, it is self-evident that the leaders are positioned as prompt if one considers that the text states that the agenda set for the meeting of the State Council Investigation Unit follows the then-already-available reflections of the national leaders. ${ }^{5}$ The discursive construction of the national leaders as responsible decision makers with individual agency represents, in our view, the same communicative implications as the use of honorifics above, i.e., the reinforcement of alignment with the public.

Alignment itself can be captured in the text if one examines its narrative features. The announcement includes seven action plans, and the fact that this action plan represents an implicit attempt to align with the public seems to be confirmed in the way that practically all of these actions are centred on two main themes:

${ }^{5}$ See Kádár \& Zhang (2019) for a detailed discussion on the relationship between alignment and time as a discursive construct. 
- The role of punishment: 3 out of 7 of action points promise punishment, which is a key characteristic of discourses emerging in response to moral crises.

- Transparency and accountability: The other 4 action points promise more transparency on the government's side, as well as more emphasis on accountability. The fact that transparency and accountability are mentioned represents a sense of self-criticism, since the fact that these issues are mentioned implies that current practices surrounding the production and control of medicine are insufficient.

The present analysis has so far examined the ways in which politeness and alignment interrelate, by illustrating that politeness moves in gong'gao texts may ultimately operate as part of the broader alignment of the text - in the data studied here, politeness is a means of attributing agency in the context of crisis, hence reinforcing public trust. In what follows, we illustrate that the situation is similar when it comes to impoliteness.

\subsection{Alignment and (im)politeness in the Trade War dataset}

The following excerpt represents the typical ways in which impoliteness operates in our Trade War dataset:

(2) 2018 年 第34号

美国时间2018年4月3日，美国政府依据301调查单方认定结果，宣布将对原产于中国 的进口商品加征 $25 \%$ 的关税, 涉及约 500 亿美元中国对美出口。美方这一措施明显违反 了世界贸易组织相关规则, 严重侵犯中方根据世界贸易组织规则享有的合法权益, 威胁中方经济利益和安全。

对于美国违反国际义务对中国造成的紧急情况，为捍卫中方自身合法权益，中国政 府依据《中华人民共和国对外贸易法》等法律法规和国际法基本原则, 将对原产于 美国的大豆等农产品、汽车、化工品、飞机等进口商品对等采取加征关税措施, 税率为25\%，涉及2017年中国自美国进口金额约500亿美元。（详见附件）

最终措施及生效时间将另行公告。

附表：对美加征关税商品清单（106项）.pdf

商务部 2018年4月4日

'Announcement of adding tariffs to part of US-produced commodities

Source: The Ministry of Commerce, People's Republic of China

April 4, 2018 15:45

Ministry of Commerce, People's Republic of China

Announcement: 2018, No. 34 
On April 3, 2018 U.S. time, the U.S. government announced to impose an additional $25 \%$ tariff on imported commodities produced by China, following the results of its unilateral decision to activate the Section 301 Investigation, which influences 50 billion US dollars' worth of exports from China to the U.S. This move by the U.S. side is a bald violation of the related WTO rules, and a severe offence to the legitimate rights and interests of the Chinese side in compliance with the WTO rules. This is a threat to the economic interests and security of the Chinese side.

Due to the emergency caused by the violation of international obligations by the U.S., in order to protect the legitimate rights and interests of the Chinese side, the Chinese government is going to take measures to add tariffs on U.S.-produced imported commodities including soybeans, cars, chemicals, and aircrafts in line with the 'Foreign Trade Law of the People's Republic of China' and other related laws and regulations, as well as the fundamental principles of international law. The tariff rate will be $25 \%$, involving 50 billion US dollars' worth of imports into China from the U.S. (See the attachment for details.)

The ultimate measures to be taken by the Chinese government and the time by which the present policies will come into force will be announced later.

Table attached: Commodity List of Tariff targeted at U.S. products (106 items).pdf

The Ministry of Commerce 4 April 2018'

Gong'gao announcements like this are impolitely-loaded, at least in the sense that they discursively construct the U.S. government as an actor with agency who is responsible for a dangerous economic situation. For instance, the text

- uses the expression jinji-qingkuang 紧急情况 'emergency' in reference to the international clash, which is a typical form of 'exaggerating rhetoric' (Harold 2007), to position the U.S. government as an irresponsible actor;

- refers to the U.S. actions as 'illegal', by using expressions such as mingxian-weifan 明显违反 'bald violation' and yanzhong-qinfan.

In a similar fashion with politeness in the Vaccine Scandal dataset, one can only speculate about whether these forms have ever been interpreted as impolite in the interpersonal sense of the word. While forms of behaviour such as irresponsive behaviour featured here are part of the inventory of making interpersonal offence in many cultures (see e.g., Culpeper et al. 2010) and calling the other irresponsible is a frequently used Chinese pragmatic tool of causing face-threat and offence (see e.g., Chen 2000), this rhetoric would generally count as 'sabre rattling' in many other political cultures (cf. Kollias et al. 2014). Note that we have conducted an internet search to confirm whether the Chinese rhetoric during the Trade War has triggered metapragmatic evaluations (Agha 2015) such as 'impolite' or 'rude' 
in the English language media, and this search has been negative. ${ }^{6}$ Thus, it seems that these forms of 'impoliteness' have been designed for 'domestic consumption' - which is a typical characteristic of alignment in political language use as Liu and Shi (in the present Special Issue) demonstrate.

The aligning function of these forms becomes even more evident if one examines them in a discursive dynamic: Along with representing the U.S. side as 'immoral', the monologue also constructs Chinese decision makers as moral, e.g., by stating that the 'Chinese side' Zhong-fang 中方 acts to 'protect its legitimate rights and interests' zishen hefa quanyi 自身合法权益. Utterances like this are in a noteworthy contrast with what we can observe in the context of the Vaccine Scandal (section 3.1), in the respect that they feature Chinese authorities with a decreased agency: a) While gong'gao texts in our data use the country name of the U.S. (Meiguo 美国) in most of the time, China tends to be featured as a 'side' (fang 方), i.e., as a party that responds to the actions of the Americans; b) China is discursively constructed as a victimised country that follows a legitimate course of action. Thus, Chinese authorities are featured with a sense of 'decreased agency', as actors that only respond to American aggression in a law-abiding way.

\subsection{The complexity of politeness in public monologues}

It is worth briefly noting that politeness (and impoliteness) in public monologues can be complex not only in the sense that it may closely interrelate with alignment, but also because there may be different types of (im)politeness in a particular monologue. For instance, in our Vaccine Scandal dataset certain gong'gao texts are issued by provincial and citylevel authorities, and in these texts one can observe politeness as an indicator of loyalty towards the national-level leaders. The following excerpt illustrates this phenomenon:

${ }^{6}$ We made a Google search $(25 / 10 / 2018)$ by inputting 'Trade War', 'Chinese' and 'U.S.' in combination with various metapragmatic evaluators, first 'impolite', then 'rude' and finally 'harsh', and this search has dropped out any news article in which such evaluators are used in reference to the language use of the Chinese in the course of the conflict. 
（3）长春长生生物科技有限责任公司违法违规生产疫苗案件发生以来, 省委副书记、 省长景俊海高度重视, 先后 16 次作出具体批示指示, [...] 7 月 23 日晚上, 景俊海连夜 主持召开案件处置工作指导组第一次会议, 传达贯彻习近平总书记重要批示指示精 神, 落实李克强总理批示指示精神 $[\ldots]$

'Since the incident of illegal vaccine production of Changchun Changsheng Biotech Ltd., the Vice Secretary of the Provincial Committee of the Chinese Communist Party and the Governor of the Province, Jing Junhai, attached great importance to the incident; so far, he has released as many as 16 specific instructions and comments relating to the incident. [...] On the very night of July 23, Mr Jing hosted the first meeting of the Guidance Group for the dissemination of the Changsheng vaccine incident, in order to study and implement the important instructions and comments made respectively by General Secretary Xi Jinping and Premier Li Keqiang.'

(from Kádár \& Zhang 2019)

The text expresses politeness towards Jing Junhai, the Governor of Jilin Province: he is positioned as an actor with a limited sense of agency, and as a loyal person who organises a set of actions to implement the instructions of the authorities. At the same time, the text includes similar honorifics as example (1), such as chuanda-guanche 传达贯彻 ('transform and implement [the order of higher authorities]') in reference to the national-level leaders who are attributed with the ultimate agency to resolve the crisis.

One can observe similar complexities in the Trade War dataset: for instance, often politeness is expressed towards third party countries who are not directly involved in the U.S.-China conflict. In a similar fashion to other forms of (im)politeness studied in this paper, it may be ambitious to argue that such expressions are polite in the interpersonal sense of the word. However, their use indicates that the authors of public monologues may play with different degrees of agency and different types of (im)politeness to reinforce alignment. The case studied here can be illustrated in our analytic model as shown in Figure 2.

In this figure, the arrows pointing from the animator of the (public) monologue towards both the national and provincial leaders indicate that in the data studied politeness may be expressed towards different actors in a single monologue. In other words, politeness is not only directed to the national leaders, arguably due to the rhetorical character of Chinese political discourses, but also expressed towards the provincial leaders, by discursively positioning them as loyal politicians and by attributing them a limited level of agency. That is, to the latter group politeness is not expressed independently but rather in dependence of the national leaders; this 'projected' use of politeness is illustrated by the line that connects the two groups of leaders in the figure. This projected politeness may reinforce alignment, in the respect that it discursively positions the decision makers 


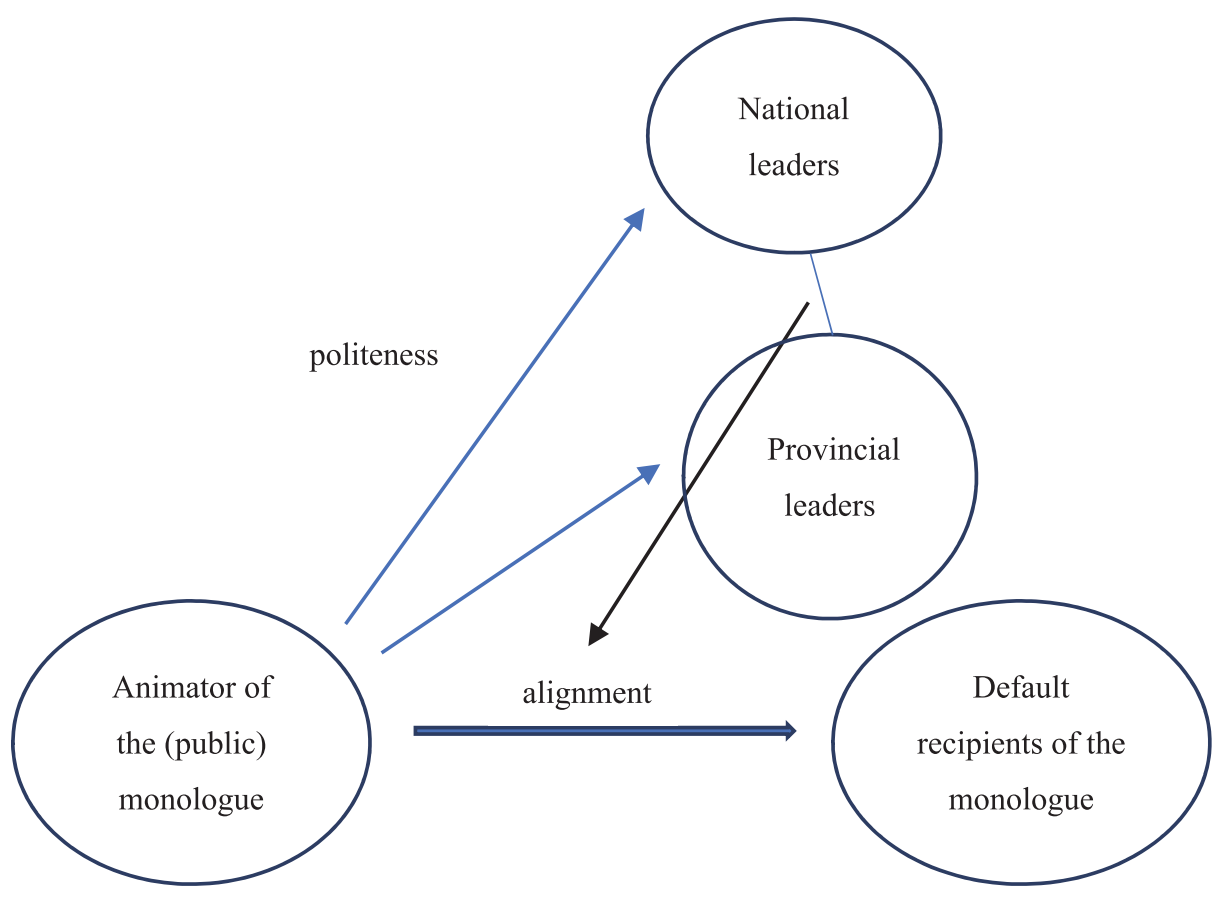

Figure 2: An example of complex politeness in public monologues

as collaborative in the context of the crisis. This is why Figure 2 includes an arrow pointing back to the arrow indicating the central pragmatic engagement of reinforcing alignment.

\section{Conclusion}

In the present paper we have examined the phenomenon of alignment, as an analytic construct that should be used in duality with 'politeness' when it comes to the analysis of monologues. While previous research (e.g., Bucholtz 2009) has examined alignment to a certain degree, little work has been done to operationalise it in connection with (im)politeness. We have demonstrated that public monologues in the political arena like the ones studied are heavily loaded with moralising and other pragmatic forms, which cannot be simply dismissed from a politeness theoretical perspective. However, they can neither be classified as '(im)polite' in the interpersonal sense, since it is dubious whether they are subject to (im)polite 
evaluations (Eelen 2001). This does not mean that they are not interrelated with (im)politeness but, as we have argued on the basis of our model illustrated by Figure 1, they are used beyond the interpersonal agenda, as part of a discursive engagement to form alignments with the public. This, in turn, points to the importance of intersubjective alignment in understanding language behaviour. Experts have devoted little attention to elaborating how the concept of alignment relates to politeness, and we believe that a contribution of our paper to politeness theory resides in that we have demonstrated that (im)politeness as an analytic construct has limited function to capture certain forms of language use that are, nevertheless, intrinsically related to (im)politeness.

As we have argued in section 1, the theoretical model proposed needs to be further tested in datatypes of other public monologues in which the person who delivers the monologue assumes the role of the principal rather than animator. In addition, there are at least two key areas that we have only touched on in this paper, and the analysis of which need further research. First, the moral aspect of language usage has recurred in our analysis: we have demonstrated that our dataset - and, allegedly, many instances of political and other forms of public discourse - are heavily loaded with moral notions, i.e., alignment-(im)politeness and morality are closely interrelated in such discourses. In recent pragmatics research, language and morality has received increased attention (see an overview in Kádár 2017), and it remains a key task for future research to examine how alignment and morality interrelate. It is clear even on the basis of the data presented here that, in forming alignment with the public, monologues tend to take moral stances, but there are various questions, such as how explicit and implicit forms of moralisation interrelate. In the present data, moralisation has been explicit, but it well may be that in other rhetorical contexts moralisation is a significantly more implicit process.

Second, while notions such as identity and agency have been touched on in our analysis, it remains a task for future research to consider how the discursive construction of agencies interrelate with what experts of identity have found (e.g., Graham 2006; Garcés-Conejos Blitvich 2016). As the brief case studied in section 5.3 has illustrated, there may be various recipients of politeness (and impoliteness) in political/public monologues, and various types of (im)politeness may be deployed towards these actors. The study of (im)politeness in such contexts may also reveal information about the culture in which the public monologue is situated: for instance, the case in section 5.3 accords with the hierarchical nature of Chinese decision making. It would be fruitful to compare cases like the one studied in this 
paper with examples drawn from other cultures. It would also be important to see whether politeness and impoliteness can be used in equally complex ways in political discourses when it comes to the construction of agency.

These questions seem to us to indicate that it is fruitful to study linguistic (im)politeness beyond the interpersonal level.

\section{Acknowledgments}

We would like to express our gratitude to the two anonymous referees for their insightful comments, which helped us to improve the quality of this manuscript. We are also indebted to Peter Bull for his advice on our terminology. We would like to say thank you for Fengguang Liu for all the support she provided during the authoring of this manuscript. Last but not least, we would like to say thank you to the editors in chief Ferenc Kiefer and Katalin É. Kiss for their support of the present project. On the institutional level, Dániel Z. Kádár would like to acknowledge the research support of both the Dalian University of Foreign Languages, China and the MTA Hungarian Academy of Sciences Lendület (Momentum) grant (LP2017/5). Sen Zhang's contribution to the present paper is based on the results of a research that has been carried out as part of the '2018 Scientific Research Fund Program (Youth Program) of Dalian University of Foreign Languages (DUFL)' (2018XJQN11). Sen would like to acknowledge the support of DUFL, which allowed him to dedicate time to co-authoring the present paper. It goes without saying that all remaining errors are our responsibility.

\section{References}

Agha, Asif. 2007. Language and social relations. Cambridge: Cambridge University Press. Agha, Asif. 2015. Tropes of slang. Signs and Society 3. 306-330.

Bhatia, Aditi. 2006. Critical discourse analysis of political press conferences. Discourse \& Society 17. 173-203.

Brown, Penelope and Stephen Levinson. 1987. Politeness: Some universals in language usage. Cambridge: Cambridge University Press.

Bucholtz, Mary. 2009. From stance to style: Gender, interaction, and indexicality in Mexican immigrant youth slang. In A. Jaffe (ed.) Stance: Sociolinguistic perspectives. Oxford: Oxford University Press. 146-170.

Bull, Peter and Anita Fetzer. 2010. Face, facework and political discourse. Revue internationale de psichologie sociale 23. 155-185.

Chen, Guo-Ming. 2000. The impact of harmony on Chinese conflict management. Paper presented at the 86th Annual Meeting of the National Communication Association (Seattle, November 9-12, 2000). https://files.eric.ed.gov/fulltext/ED456490.pdf

Chen, Xinren. 2017. Extensions of the Chinese passive construction: A memetic account. East Asian Pragmatics 2. 59-74.

Cooren, François. 2008. Between semiotics and pragmatics: Opening language studies to textual agency. Journal of Pragmatics 40. 1-16. 
Culpeper, Jonathan, Leyla Marti, Meilian Mei, Minna Nevala and Schauer, Gila. 2010. Cross-cultural variation in the perception of impoliteness: A study of impoliteness events reported by students in England, China, Finland, Germany and Turkey. Intercultural Pragmatics 7. 597-624.

Eelen, Gino. 2001. A critique of politeness theories. Manchester: St Jerome.

Flowerdrew, John. 1999. Face in cross-cultural political discourse. Text 19. 3-23.

Garcés-Conejos Blitvich, Pilar. 2010. A genre approach to the study of im-politeness. International Review of Pragmatics 2. 46-94.

Garcés-Conejos Blitvich, Pilar. 2013. Introduction: Face, identity and im/politeness. Looking backward, moving forward: From Goffman to practice theory. Journal of Politeness Research 9. 1-33.

Goffman, Erving. 1981. Forms of talk. Philadelphia: The University of Pennsylvania Press.

Goodwin, Charles. 2007. Participation, stance and affect in the organization of activities. Discourse \& Society 18. 53-73.

Graham, Sage. 2007. Disagreeing to agree: Conflict, (im)politeness and identity in a computer-mediated community. Journal of Pragmatics 39. 742-759.

Harold, Christine. 2007. Pranking rhetoric: 'culture jamming' as media activism. Critical Studies in Media Communication 21. 189-211.

Harris, Sandra, Karen Grainger and Louise Mullany. 2006. The pragmatics of political apologies. Discourse \& Society 17. 717-736.

He, Ziran and Wei Ren. 2016. Current address behaviour in China. East Asian Pragmatics 1. $163-180$.

Huckin, Thomas. 2002. Critical discourse analysis and the discourse of condescension. In: E. Barton and G. Stygall (eds.) Discourse studies in composition. Cresskill, NJ.: Hampton Press.

Jiang, Xiangying. 2006. Cross-cultural pragmatic differences in US and Chinese press conferences: The case of the North Korea Nuclear crisis. Discourse \& Society 17. 237-257.

Johnson, Sarah. 2017. Agency, accountability and affect: Kindergarten children's orchestration of reading with a friend. Learning, Culture and Social Interaction 12. 15-31.

Jong, Markus de, Mariët Theune and Dennis Hofs. 2008. Politeness and alignment in dialogues with a virtual guide. Aamas '08: Proceedings of the 7th International Joint Conferences On Autonomous Agents And Multiagent Systems 1. 207-214. https://dl.acm.org/citation.cfm?id=1402416

Kádár, Dániel Z. 2017. Politeness, impoliteness and ritual: Maintaining the moral order of interpersonal interaction. Cambridge: Cambridge University Press.

Kádár, Dániel Z. 2019. Introduction: Advancing linguistic politeness theory by using Chinese data. Acta Linguistica Academica 66. 149-164.

Kádár, Dániel Z. and Jonathan Culpeper. 2010. Historical (im)politeness: An introduction. In J. Culpeper and D. Z. Kádár (eds.) Historical (im)politeness. Berne: Peter Lang. $9-35$.

Kádár, Dániel Z. and Michael Haugh. 2013. Understanding politeness. Cambridge: Cambridge University Press.

Kádár, Dániel Z. and Sen Zhang. 2019. Intersubjectivity and implicitness in Chinese political discourses: A case-study of the 2018 vaccine scandal'. Journal of Language and Politics. https://doi.org/10.1075/jlp.18053.kad 
Kollias, Christos, Stephanos Papadamou and Psarianos, Iacovos. 2014. Rogue state behaviour and markets: The financial fallout of North Korean nuclear tests. Peace Economics, Peace Science and Public Policy 20. 267-292.

Leech, Geoffrey. 2008. Language in literature: Style and foregrounding. London: Taylor \& Francis.

Liu, Fengguang and Wenrui Shi. 2019. Political advice in Chinese political discourse(s). Acta Linguistica Academica 66. 209-228.

Locher, Miriam. 2006. Polite behaviour within relational work: The discursive approach to politeness. Berlin \& New York: Mouton de Gruyter.

Locher, Miriam and Richard Watts. 2005. Politeness theory and relational work. Journal of Politeness Research 1. 9-33.

Roche, Jennifer, Rick Dale and Gina Caucci. 2010. Doubling up on double meaning: Pragmatic alignment. Language and Cognitive Processes 27. 1-24.

Schafer, John C. 1981. The linguistic analysis of spoken and written texts. In: B. M. Crall and R. J. Vann (eds.), Exploring speaking-writing relationships: Connections and contrasts. Urbana, IL: National Council of Teachers of English. 1-31.

Schermerhorn, John and Michael Bond. 1997. Cross-cultural leadership dynamics in collectivism and high power distance settings, Leadership \& Organization Development Journal 18. 187-193.

Spencer-Oatey, Helen (ed.). 2000. Culturally speaking. London: Continuum.

Spencer-Oatey, Helen and Vladimir Žegerac. 2017. Power, solidarity and (im)politeness. In: J. Culpeper, M. Haugh and D. Z. Kádár (eds.) The Palgrave handbook of linguistic (im)politeness. Basingstoke: Palgrave Macmillan, 119-141.

Tanaka, Hideki, Stephen Nightingale, Hideki Kashioka, Kenji Matsumoto, Masamchi Nishiwaki, Tadashi Kumano and Maruyama, Takehiko. 2002. Speech to speech translation system for monologues-data driven approach. ICSLP-2002. 1717-1720.

Tracy, Karen. 2017. Facework and (im)politeness in political exchanges. In J. Culpeper, M. Haugh and D. Z. Kádár (eds.) The Palgrave handbook of linguistic (im)politeness. Basingstoke: Palgrave Macmillan. 739-757.

Watts, Richard. 2003. Politeness. Cambridge: Cambridge University Press.

Yang, Mayfair. 1997. Mass media and transnational subjectivity in Shanghai: Notes on (re)cosmopolitanism in a Chinese metropolis. In A. Ong and D. Nonini (eds.) Ungrounded empires: The cultural politics of modern Chinese transnationalism. New York: Routledge. 287-321.

Open Access. This is an open-access article distributed under the terms of the Creative Commons Attribution 4.0 International License (https://creativecommons.org/licenses/ by/4.0), which permits unrestricted use, distribution, and reproduction in any medium, provided the original author and source are credited, a link to the CC License is provided, and changes - if any - are indicated. (SID_1) 